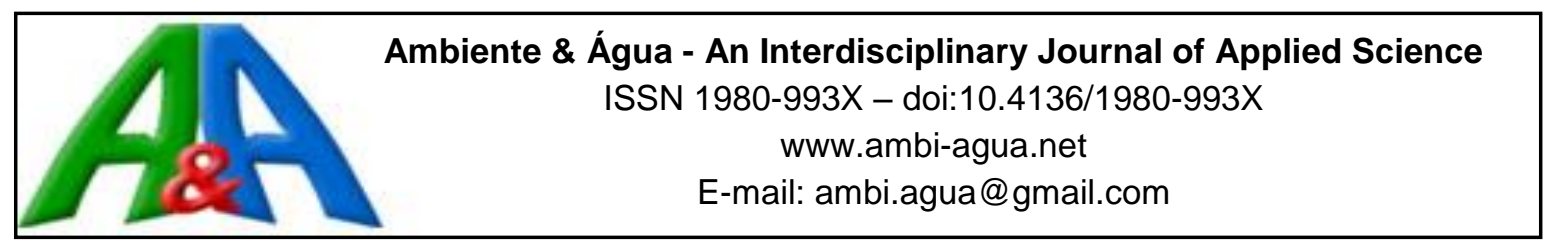

\title{
Electron Spin Resonance (ESR) in detection of aquatic pollution through host-parasite relationship
}

\author{
ARTICLES doi:10.4136/ambi-agua.2085
}

Received: 20 Mar. 2017; Accepted: 09 Sep. 2018

\author{
Lucas Aparecido Rosa Leite'; Angela Kinoshita'; Oswaldo Baffa²; \\ Rodney Kozlowiski de Azevedo ${ }^{1}$; Vanessa Doro Abdallah ${ }^{1 *}$ \\ ${ }^{1}$ Universidade do Sagrado Coração (USC), Bauru, SP, Brasil \\ Programa de Mestrado em Ciência e Tecnologia Ambiental. \\ E-mail: lucas.leite@aedu.com, angelamitie@gmail.com, azevedork@gmail.com, \\ vanessaabdallahusc@gmail.com \\ ${ }^{2}$ Universidade de São Paulo (USP), Ribeirão Preto, SP, Brasil \\ Faculdade de Filosofia, Ciências e Letras de Ribeirão Preto (FFCLRP). \\ Departamento de Física (DF). E-mail: baffa@usp.br \\ *Corresponding author
}

\begin{abstract}
Aquatic environmental pollution due to negative human activities remains a major problem. Bioindicators that primarily describe the total concentration of the respective pollutant are very useful tools to aid in the chemical analysis of water in order to obtain knowledge about the levels of pollutants in the environment. This study therefore used Electron Spin Resonance Spectroscopy (ESR) to detect the presence of transition metals (copper, iron and manganese) and possible radicals present in samples of Neoechinorhynchus curemai and its host tissues Prochilodus lineatus, as well in water and sediment of the Batalha River, at the same sample site where fish were collected. Spectral analysis of samples showed the presence of three metals $\left(\mathrm{Cu}^{2+}, \mathrm{Fe}^{3+}\right.$ and $\left.\mathrm{Mn}^{2+}\right)$, in addition to nitric oxide (NO) and humic acid (HA). Quantification of the elements in the samples was possible only for $\mathrm{Cu}$ detected in the spectrum of parasites, which was equivalent to $2 \mathrm{ppm}$. ESR proved to be efficient in the detection of transition-metal ions $\left(\mathrm{Cu}^{2+}, \mathrm{Fe}^{3+}\right.$ and $\left.\mathrm{Mn}^{2+}\right)$, in addition to $\mathrm{NO}$ and $\mathrm{HA}$. However, the low concentration values of these compounds in P. lineatus tissues (liver, muscle and intestine) and in the water and sediment samples collected did not allow their quantification, as they were below the limit of detection. It can be concluded that $N$. curemai had the capacity to accumulate these ions, especially copper.
\end{abstract}

Keywords: environmental monitoring, free radicals, Neoechinorhynchus curemai, Prochilodus lineatus, transition metals.

\section{Ressonância do Spin Eletrônico (ESR) na detecção de poluição aquática através da relação parasito-hospedeiro}

\section{RESUMO}

A poluição de ambientes aquáticos em decorrência de atividades antrópicas negativas permanece sendo um grande problema. Para se obter conhecimento acerca dos níveis biológicos de poluentes disponíveis no meio, os bioindicadores tornam-se uma ferramenta muito útil no 
auxílio das análises químicas da água que primariamente descrevem a total concentração do respectivo poluente. Nesse contexto, o objetivo desse trabalho foi o de empregar a técnica de Espectroscopia de Ressonância do Spin Eletrônico (ESR) para detectar a presença de poluentes, diretamente em espécimes de Neoechinorhynchus curemai e nos tecidos do seu hospedeiro Prochilodus lineatus, assim também como na água e sedimento do rio Batalha, no mesmo ponto onde os peixes foram coletados. A análise do espectro das amostras identificou a presença de três metais $\left(\mathrm{Cu}^{2+}, \mathrm{Fe}^{3+}\right.$ e $\left.\mathrm{Mn}^{2+}\right)$, além do óxido nítrico (NO) e do ácido húmico (AH). A quantificação dos elementos nas amostras só foi possível para o $\mathrm{Cu}$, detectado no espectro dos parasitos, que foi de $2 \mathrm{ppm}$. A ESR se mostrou eficiente na detecção de íons metálicos de transição $\left(\mathrm{Cu}^{2+}, \mathrm{Fe}^{3+}\right.$ e $\left.\mathrm{Mn}^{2+}\right)$, além do $\mathrm{NO}$ e do $\mathrm{AH}$. Entretanto, a baixa concentração desses compostos nos tecidos (fígado, músculo e intestino) de $P$. lineatus. não possibilitaram sua quantificação, já que as concentrações dos mesmos estão abaixo do limite de detecção do aparelho. É possível concluir que $N$. curemai teve a capacidade de acumular esses íons, especialmente cobre.

Palavras-chave: metais de transição, monitoramento ambiental, Neoechinorhynchus curemai, Prochilodus lineatus, radicais livres.

\section{INTRODUCTION}

Pollution of aquatic ecosystems as a result of anthropogenic activities remains a major problem in these environments, causing disastrous effects on the health of living organisms and becoming subject of many discussions (Khan and Thulin, 1991; Sures, 2008). In freshwater ecosystems, both organic and inorganic pollution (especially metals) are global issues and deserve attention since they directly and indirectly affect organisms, causing them irreparable damage (Wen et al., 2017; Schmeller et al., 2018; Väänänen et al., 2018).

Bioindicators that primarily describe the total concentration of a respective pollutant are very useful tools in the chemical analyses of water in order to obtain knowledge about levels of pollutants in the environment. Recent studies have shown that, in addition to already established indicators, certain parasites and their hosts can be used as biomonitoring tools, since the pollution also effects their health and, consequently, their occurrence and distribution. Another important point to consider is that, just like pollutants, parasites affect the health of organisms, and some of these organisms' responses to pollutants and parasites are very similar (Lafferty, 2008; Lafferty and Kuris, 2005; Sures, 2008; Thielen et al., 2004).

Studies evaluating the role of parasites as accumulators and pollution indicators have been carried out for decades, using a vast host-parasite combination (Sures et al., 1999; 2017) where fish are the most frequently used hosts (Vidal-Martínez and Wunderlich, 2017). In addition, the high potential of parasites for metal accumulation (especially heavy metals) and their high effectiveness in assessing aquatic pollution compared to free-living organisms (such as mussels, for example) has been clearly demonstrated (Sures et al., 1997; 1999;).

Different fish endoparasites have been suggested for use in the detection of pollution in aquatic environments. Among them, acanthocephalans are highlighted as presenting a high capacity for heavy metal accumulation (Vidal-Martínez et al., 2009; Nachev et al., 2013). Laboratory studies have shown that fish parasitized by acanthocephalans have lower levels of heavy metal contamination in their tissues when compared to non-parasitized specimens. However, the results of the analyses are difficult to predict, and there is a need for further studies in this field to contextualize information already obtained in different types of environments with different levels of degradation (Thielen et al., 2004; Sures, 2008).

Usually bioaccumulation studies in the host-parasite relationship are made using inductively coupled plasma mass spectrometry (ICP-MS) (Brázová et al., 2012; 2015; Leite et 
al., 2017; Nachev et al., 2010; 2013; Thielen et al., 2004) or Atomic absorption spectrometry (AAS) (Baruš et al., 2001; Bayoumy et al., 2015; Baruš et al., 2007; Dural et al., 2011; Morsy et al., 2012). Eletron Spin Resonance (ESR) is a spectroscopy designed to detect non-zero electronic spin systems, such as free radicals and some transition metals. In biological systems, it can be used to detect the presence of some ions, including copper, manganese and iron, directly in tissues without biochemical manipulations, thus reducing the risk of structural disturbances. This makes the technique a powerful tool in research involving biological and environmental systems (Wertz and Bolton, 2012).

ESR has already been used to detect pollutants (both organic and inorganic) in several systems. In aquatic ecosystems, ESR has been used to detect Reactive Oxygen Species (ROS) in amphibians (D'Errico et al., 2018) and to detect and quantify $\mathrm{Mn}^{2+}$ in fish otoliths (Di Beneditto and Franco, 2018). In both cases the technique proved to be efficient, and could be used to aid other spectrometric techniques. In the host-parasite system, however, there are still no published studies where ESR was used. In this context, the objective of this study was to use the ESR technique to detect transition metals (copper, iron and manganese) and possible radicals present in parasites and host tissues (muscle, liver and intestine).

\section{MATERIAL AND METHODS}

\subsection{STUDY AREA}

This study was conducted in a stretch of the Batalha River, the Tietê-Batalha River Basin, located in the municipality of Reginópolis, State of São Paulo (21'53'17' S and 49¹3'31' W). It is an area with severe anthropic influences and predominantly lotic characteristics. Limnologic and structure variables of the stretch are plotted in Table 1.

The river area in this stretch, even though surrounded by native riparian forest for most of its extension, is used predominantly for agricultural and livestock purposes, with emphasis on cattle raising, sugar cane, corn and eucalyptus plantations, increasing the amount of organic matter and leachate pollutants. In addition, the municipality does not treat sewage, and so sewage is thrown in natura into a tributary of the river (São Paulo, 2010; Santos and Heubel, 2008; Sistema Nacional De Informações Sobre Saneamento, 2016).

Table 1. Mean values of physicochemical parameters: $\mathrm{pH}$, temperature, dissolved oxygen (DO) and conductivity (CD); and structural parameters: width of the stretch, and width of the permanent preservation area (APP) surrounding the sampling point, located in the municipality of Reginópolis.

\begin{tabular}{lc}
\hline Parameter & Value \pm SD \\
\hline $\mathrm{pH}$ & $7.7 \pm 0.3$ \\
Temperature $\left({ }^{\circ} \mathrm{C}\right)$ & $26.5 \pm 1.5$ \\
$\mathrm{DO}(\mathrm{mg} / \mathrm{L})$ & $4.9 \pm 1.6$ \\
$\mathrm{CD}(\mu \mathrm{S} / \mathrm{cm})$ & $68 \pm 14.7$ \\
Width $(\mathrm{m})$ & $13.2 \pm 1.7$ \\
APP width $(\mathrm{m})$ & $83.1 \pm 7.9$ \\
\hline
\end{tabular}

\subsection{SAMPLING AND PROCESSING OF PARASITES AND HOSTS}

Thirty-nine specimens of Prochilodus lineatus (Valenciennes, 1837) (Characiformes: Prochilodontidae) were collected between May 2015 and May 2016 on the Batalha River. Fish were necropsied in the laboratory, and the internal organs were analyzed separately using a 
stereomicroscope to collect parasites. In this study, only fish specimens that showed positive results for Neoechinorhynchus curemai Noronha, 1973 (Acanthocephala: Neoechinorhynchidae) parasitism were used, totaling 19 P. lineatus specimens analyzed.

After collection, the parasites were placed in a recepticle containing distilled water and then washed with a vortex mixer. Subsequently, they were placed in glass flasks and frozen at $-20^{\circ} \mathrm{C}$ until the ESR analysis. Samples of muscle, liver and intestine were also taken from hosts. The washing and storage of the tissue samples followed the same methodology used for parasites.

\subsection{WATER AND SEDIMENT SAMPLING}

Water and sediment samples were collected from the Batalha River at the same point of the fish collection. The sampling followed the procedures recommended by Gomes and Filizola (2006) for sediment and Pires et al. (2006) for water. The samples were stored in $20 \mathrm{~mL}$ plastic tubes and frozen at $-20^{\circ} \mathrm{C}$ until ESR analysis.

\subsection{ESR ANALYSIS}

Samples of parasites and host tissues were externally cleaned with ultrapure water (Milli Q) and then dehydrated in absolute alcohol by immersion for 10 minutes. These materials and sediment were then oven-dried at $40^{\circ} \mathrm{C}$ (Table 2). After drying, the samples were carefully crushed with agate mortar and pestle for homogenization under low impact, in order to avoid induction of other radicals by mechanical action. Subsequently, an aliquot of each sample was transferred to an ESR quartz tube, with a $3 \mathrm{~mm}$ internal diameter. The mass used to record the spectrum was determined (Table 2). The water sample was placed in a capillary tube and sealed prior to insertion in the quartz tube. The tube containing the sample was inserted into a quartz dewar for freezing with liquid nitrogen for spectrum recording $(77 \mathrm{~K})$.

A JEOL Band-X spectrometer was used to record the spectra, some of them with a scan width of $500 \mathrm{mT}$ and others with $80 \mathrm{mT}$, centered on the g 2 spectral region. Some spectra were recorded simultaneously with a $\mathrm{Mn}^{2+}$ standard, present in the spectrometer, that consists of $\mathrm{MgO}$ crystal doped with $\mathrm{Mn}^{2+}$. A $0.5 \mathrm{mM}$ solution of $\mathrm{CuSO}_{4}$ complexed with $\mathrm{C}_{3} \mathrm{H}_{7} \mathrm{NO}_{2}$ was used for the quantification of copper $\left(\mathrm{Cu}^{2+}\right)$ present in the sample. The spectra of the parasite and the copper solution were acquired under the same spectrometer conditions of microwave power, modulation and gain. Copper can be complexed with several compounds producing different spectral symmetries. Alanine was used as a ligand due to the same symmetry of the complex found in the parasites samples. The volume of the standard solution used was $20 \mu \mathrm{L}$.

Table 2. Mass values (mg) of parasites, host tissues and sediment samples before and after drying, and the amount used in ESR analysis.

\begin{tabular}{lccccc}
\hline Mass & Parasite & Intestine & Liver & Muscle & Sediment \\
\hline Wet & $102 \mathrm{mg}$ & $189.5 \mathrm{mg}$ & $690 \mathrm{mg}$ & $674.4 \mathrm{mg}$ & -- \\
Dry & $17.1 \mathrm{mg}$ & $20.21 \mathrm{mg}$ & $77.44 \mathrm{mg}$ & $114 \mathrm{mg}$ & -- \\
ESR & $5.68 \mathrm{mg}$ & $6.08 \mathrm{mg}$ & $24.45 \mathrm{mg}$ & $5.8 \mathrm{mg}$ & $77.6 \mathrm{mg}$ \\
\hline
\end{tabular}

\section{RESULTS AND DISCUSSION}

The specimens of $P$. lineatus showed mean standard length and weight of $27.44 \pm 6.37 \mathrm{~cm}$ and $568.38 \pm 318.14 \mathrm{~g}$, respectively. The specimens of $N$. curemai were all adults and had mean abundance of $2.83 \pm 0.12$ parasites per fish and mean intensity of $5.52 \pm 0.13$ parasites.

The analysis of the parasite samples' spectrum in the $500 \mathrm{mT}$ scan was performed under two conditions: only parasite, and parasite with $\mathrm{Mn}^{2+}$ as a secondary standard. The analysis of 
the obtained signals showed that there is no $\mathrm{Mn}^{2+}$ in the parasite samples (Figure 1A). In the spectrum of the central region $\mathrm{g} \sim 2$ it was possible to notice characteristic lines of copper (Figure 1B). To confirm the presence of $\mathrm{Cu}^{2+}$ in the sample, spectral simulation of the $\mathrm{Cu}^{2+}$ present in the parasites was carried out using Simfonia-Bruker software. Through the simulation, it was possible to observe the agreement between the simulated $\mathrm{Cu}^{2+}$ signal and the radical present in the parasites. Double integration of the $\mathrm{Cu}^{2+}$ simulated signal was compared to element pattern spectrum. The $\mathrm{Cu}^{2+}$ mass of the total mass of the parasite was obtained from the atomic mass of the ion $(63.6 \mathrm{~g})$, resulting in a concentration of $2 \mathrm{ppm}$ of $\mathrm{Cu}^{2+}$ in the parasites (Figure $1 \mathrm{C}$ ).
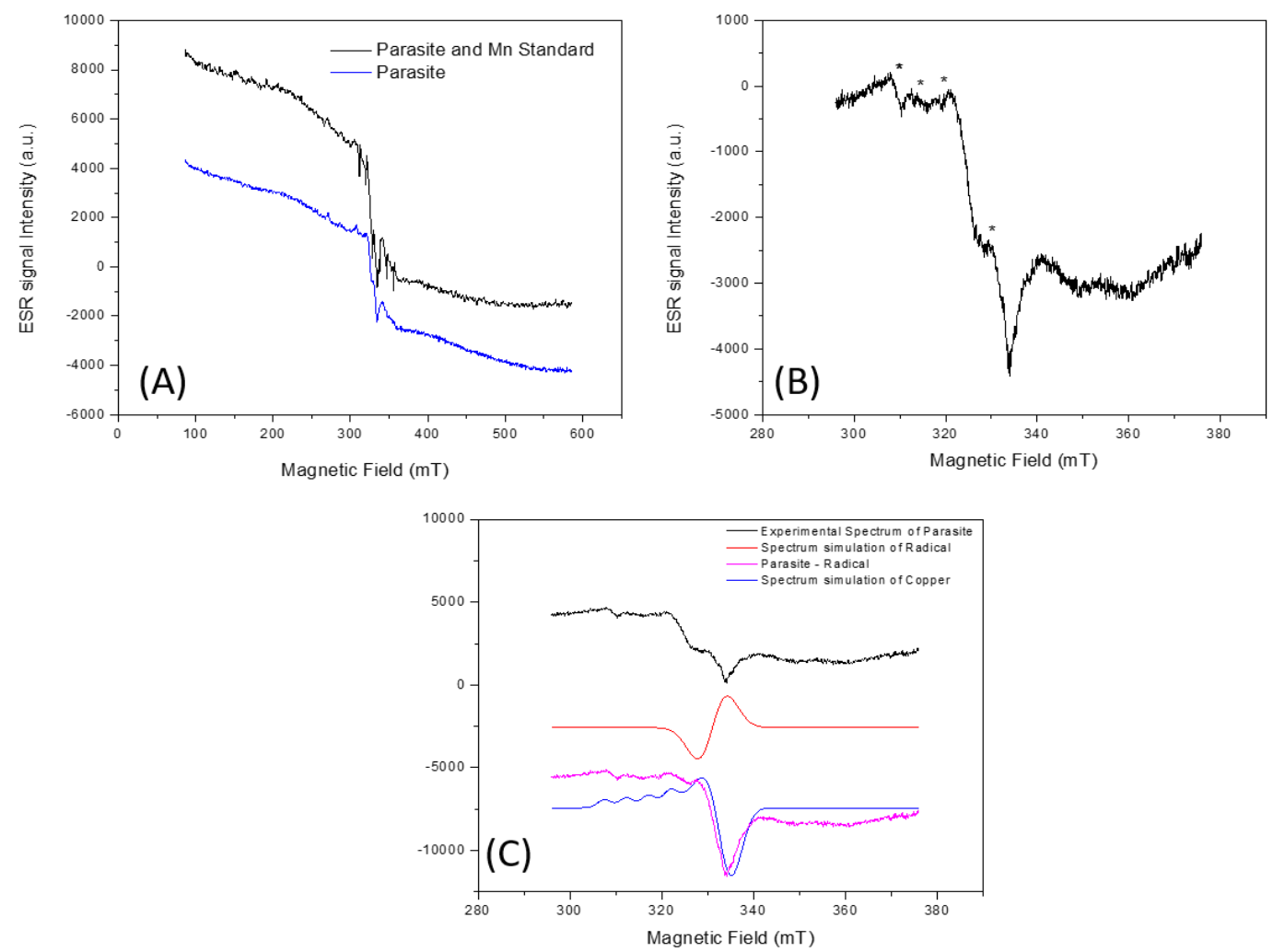

Figure 1. ESR spectrum of Neoechinorhynchus curemai specimens with and without the simultaneous register of manganese (A), centered on the $\mathrm{g} \sim 2$ region, where the signals indicated by asterisks represent the lines belonging to the copper $(B)\left(g_{\perp}: 2.0032 \pm 0.0001\right.$; $\left.\mathrm{g}_{/ /:}: 2.1160 \pm 0.0001 ; \mathrm{A}_{\perp}: 1.1 \pm 0.1 \mathrm{mT} ; \mathrm{A}_{/ /:} 4.8 \pm 0.1 \mathrm{mT}\right)$ and spectral simulation of the radical (g-factor: $2.0084 \pm 0.0001$ ) (C). Acquisition parameters are: Center Field $336 \mathrm{mT}$, Modulation Frequency $100 \mathrm{kHz}$, Modulation amplitude $0.1 \mathrm{mT}$, gain 2000, microwave frequency 9131.4 MHz, Microwave Power $5 \mathrm{~mW}$. In (A) sweep width 500mT and (B) 80 $\mathrm{mT}$.

The liver sample spectrum was recorded with 500mT scanning width. The spectrum was dominated by iron, as shown in the simulation (Figure 2A). In the $\mathrm{g} 22$ region of the spectrum it was possible to identify other radicals. By performing a more detailed recording of the spectrum in the $\mathrm{g} \sim 2$ region it was possible to observe a structure of lines. The spectrum was recorded with the manganese pattern for investigation, where very weak signals of this ion in this region can be noted (Figure 2B), indicating a small concentration of $\mathrm{Mn}^{2+}$ in the tissue. A more detailed scan at the g 2 region showed that the lines' structure in the central region corresponds to nitric oxide (NO), bound to $\mathrm{Fe}^{3+}$, leading to the three-line structure observed. Figure $2 \mathrm{C}$ shows the spectrum of the liver sample and the simulation of the NO radical spectrum. 

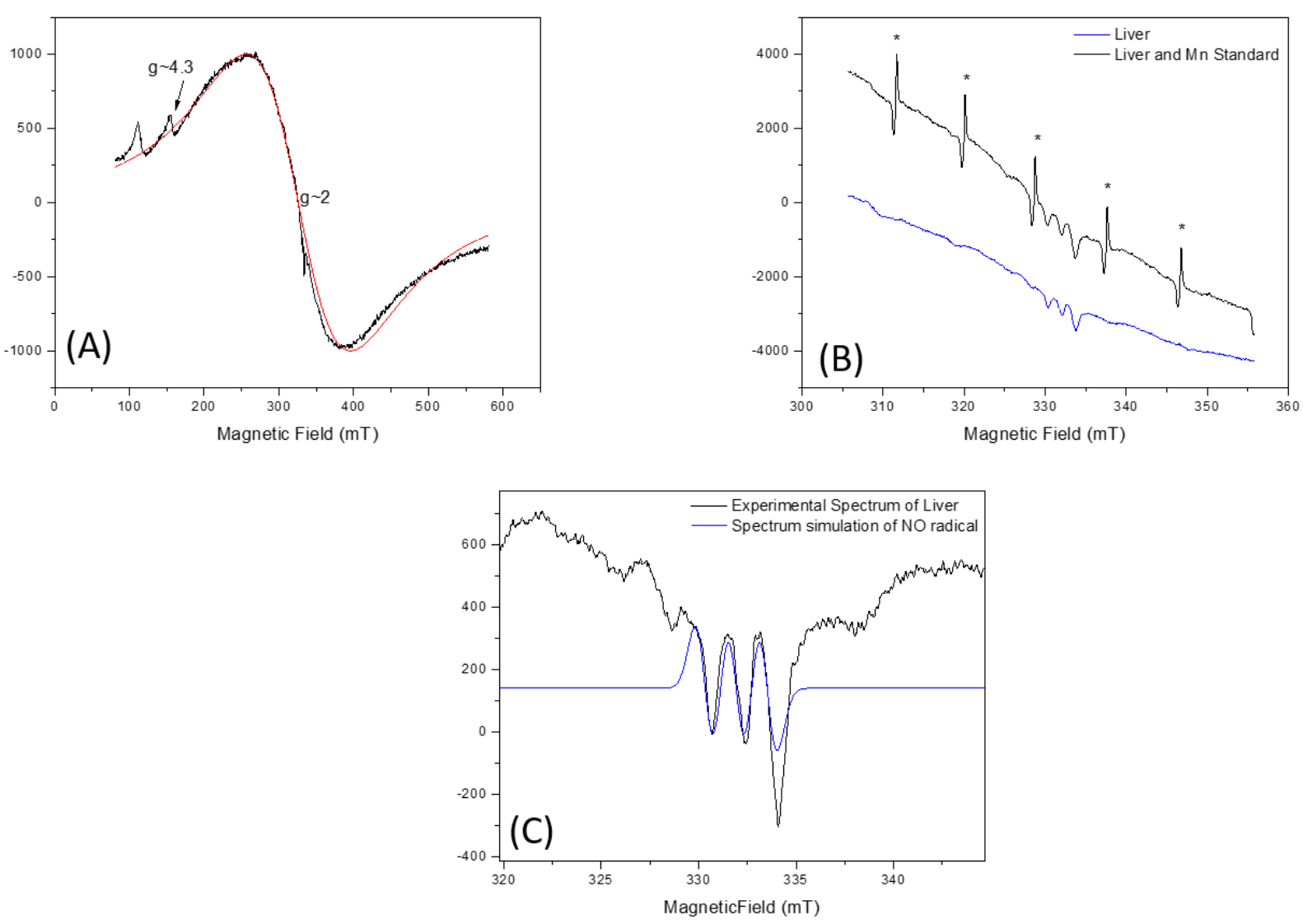

Figure 2. ESR spectrum in the $500 \mathrm{mT}$ scan of the fish liver samples and iron spectral simulation in red (A) (g-factor $=2.0453 \pm 0.0001)$. The spectrum centered on the $\mathrm{g} 2$ region with and without the manganese $(*)$ pattern (B). Spectrum of the sample also centered on the $\mathrm{g} \sim 2$ region and the simulation of the NO (g-factor $=2.0040 \pm 0.0001, \mathrm{~A}=1.82 \pm 0.01 \mathrm{mT}$ ) present in the sample $(\mathrm{C})$. Acquisition parameters are: Center Field $330 \mathrm{mT}$, Modulation Frequency $100 \mathrm{kHz}$, Modulation amplitude $0.1 \mathrm{mT}$, gain 300, microwave frequency $9133.4 \mathrm{MHz}$, Microwave Power $5 \mathrm{~mW}$. In (A) sweep width 500mT and (B) $100 \mathrm{mT}$.

In the spectrum of fish intestine samples, it was possible to notice the presence of $\mathrm{Fe}^{3+}$ and $\mathrm{Mn}^{2+}$ (Figure 3A). The spectrum was recorded with $\mathrm{Mn}^{2+}$ standard to confirm the presence of this element in the sample (Figure 3B). Incorporation of manganese ions in different matrices have been studied with multifrequency ESR, and this can give more information about the complex formed; but these techniques are not easily found, and these studies have corroborated the experiments done at X band (Murzakhanov et al., 2017).

In the fish muscle spectrum, it was also possible to notice the presence of the $\mathrm{Fe}^{3+}$ element and $\mathrm{Mn}^{2+}$ traces (Figure 4), suggesting that this element, although present in the sample, was in low concentration. 

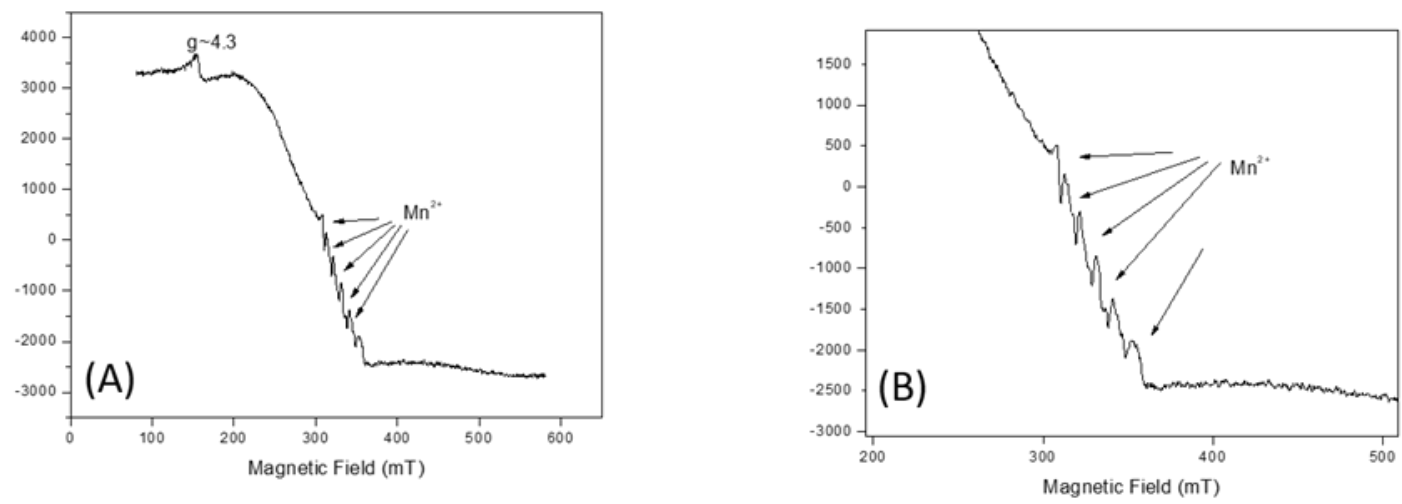

Figure 3. ESR spectrum of the fish intestine samples centered in the $g \sim 2$ region where the presence of iron is noted, with a peak at g 4.3 and manganese, as indicated (A). Spectrum in the $\mathrm{Mn}^{2+}$ region, recorded with manganese standard, for confirmation (B). Acquisition parameters are: Center Field $330 \mathrm{mT}$, Modulation Frequency $100 \mathrm{kHz}$, Modulation amplitude $0.1 \mathrm{mT}$, gain 300, microwave frequency $9133.4 \mathrm{MHz}$, Microwave Power $5 \mathrm{~mW}$, sweep width $500 \mathrm{mT}$.

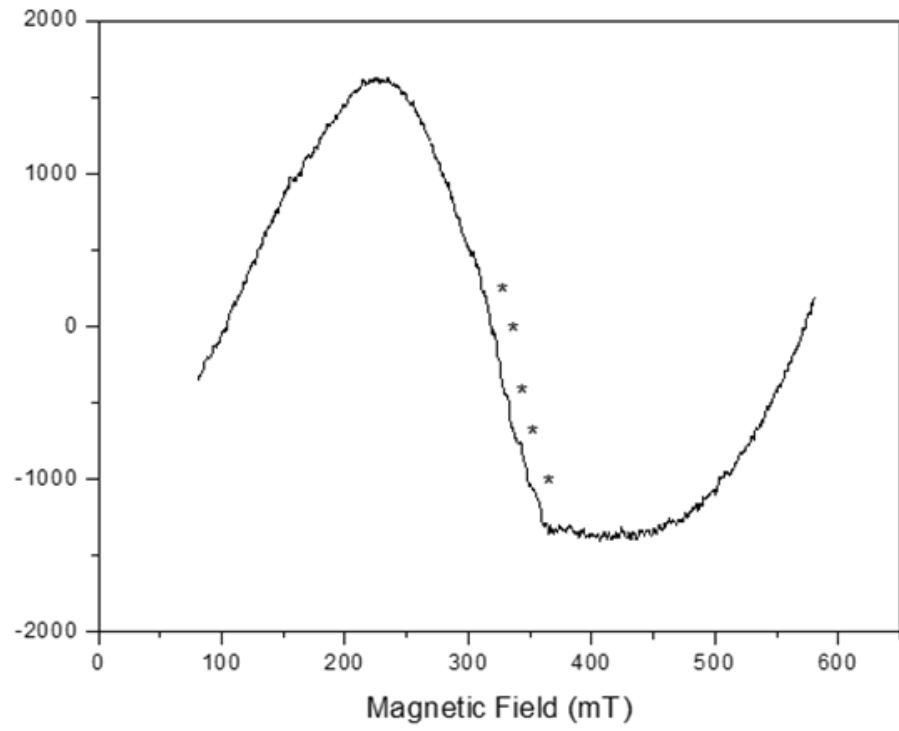

Figure 4. ESR spectrum of the fish muscle samples, where the presence of iron is observed and traces suggesting the presence of manganese $(*)$. Acquisition parameters are: Center Field $330 \mathrm{mT}$, Modulation Frequency $100 \mathrm{kHz}$, Modulation amplitude $0.1 \mathrm{mT}$, gain 300 , microwave frequency $9133.4 \mathrm{MHz}$, Microwave Power $5 \mathrm{~mW}$, sweep width $500 \mathrm{mT}$.

In the spectrum of the sediment samples analyzed, the presence of $\mathrm{Fe}^{3+}$ and $\mathrm{Mn}^{2+}$ can be observed. In addition to these elements, another central radical was recorded in the $\mathrm{g} \sim 2$ region, attributed to humic acid (AH) (Figure 5B). In the water sample, the spectrum showed only the presence of $\mathrm{Fe}^{3+}$ (Figure 5A).

Low concentrations of elements considered essential, that is, those necessary for the development of organisms and that occur naturally in the environment (Merian et al., 2004), are expected in acanthocephalans fish parasites, which are more susceptible to accumulate high concentrations of toxic elements (Nachev et al., 2013). Although copper is considered essential and is involved in several metabolic processes of living organisms (Momčilović, 2004), it is a heavy metal and at higher concentrations can bring potential risks to the health of animals, including humans (Papagiannis et al., 2004). The impacts of copper on the aquatic environment

\section{IPABH}

Rev. Ambient. Água vol. 13 n. 6, e2085 - Taubaté 2018 
depend on water physico-chemical characteristics, such as alkalinity, hardness and $\mathrm{pH}$ (Carvalho and Fernandes, 2006). Generally, concentrations of this element in water are lower than those found in fish and parasites (Porto and Ethur, 2009; Brázová et al., 2012), and the maximum concentration of copper allowed for Class 2 waters, such as the Batalha River, is $0.009 \mathrm{mg} / \mathrm{L}$ (Conama, 2005). In this case, as the element was not detected in fish-tissue spectrums nor in the water or sediment collected from the river, it was assumed that the concentrations are below the ESR detection limit.
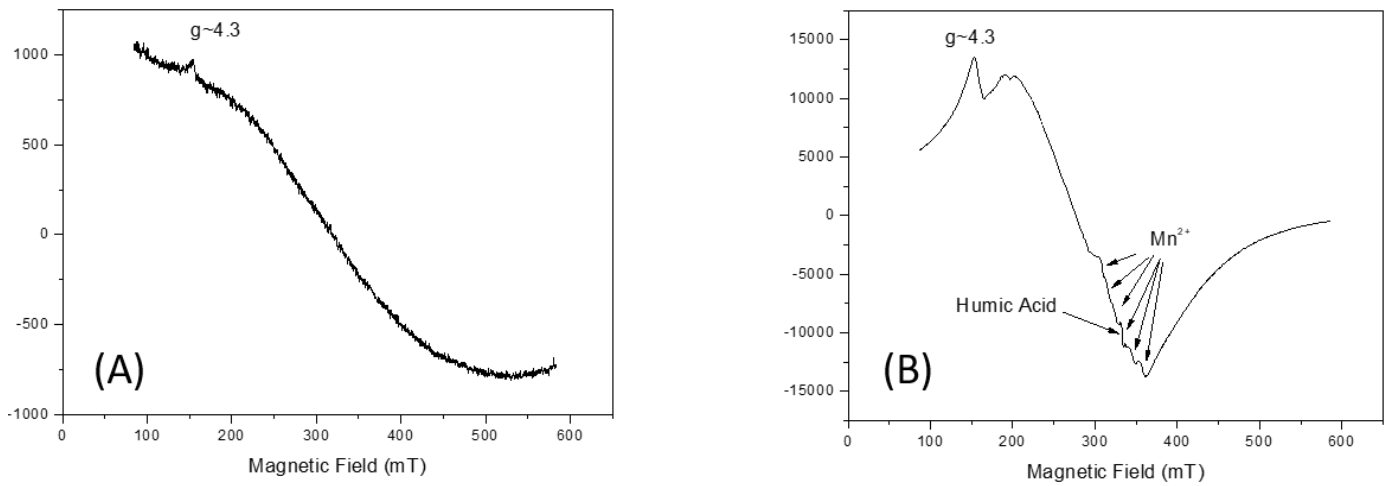

Figure 5. ESR spectrum of the water sample, where the presence of iron $(\mathrm{A})$ is noted. The ESR spectrum of sediment sample shows the presence of iron, traces of manganese, as indicated, and the presence of humic acid in the $\mathrm{g} 2$ region $(\mathrm{g}$-factor $=1.9976 \pm 0.0001$ ) (B). Acquisition parameters are: Center Field $330 \mathrm{mT}$, Modulation Frequency $100 \mathrm{kHz}$, Modulation amplitude $0.1 \mathrm{mT}$, gain 300, microwave frequency $9133.4 \mathrm{MHz}$, Microwave Power $5 \mathrm{~mW}$, sweep width 500mT.

The presence of iron and manganese ions in the spectrum of the tissues (liver, muscle and intestine) of $P$. lineatus and also in the samples of water and sediment of the Batalha River was already expected due to the high natural occurrence of these elements, which are the two most abundant metals in the environment (Förstner and Wittmann, 1983). Both elements in water and sediment are considered essential for both flora and fauna (Howe et al., 2004; Schümann and Elsenhans, 2004). Iron in fish acts mainly in oxidation-reduction and oxygen-transport processes, occurring as a component of the respiratory pigment (heme), as hemoglobin and myoglobin, as well as the heme enzymes (peroxidase, catalase and cytochromes) being absorbed from the water through the gills (Lim et al., 2001). Manganese plays a key role in the metabolism of amino acids, lipids, proteins and carbohydrates, besides being involved in functions of the immune system, blood glucose regulation, reproduction and also in defense mechanisms against free radicals (Keen et al., 1999).

In aquatic vertebrates, iron excess can cause several effects such as breathing problems, reduced growth, feeding difficulties, high mortality and histopathological changes in liver cells (Bury et al., 2003; Lim et al., 2001), in addition to the production of oxygen free radicals, which may be toxic to cells (Bury et al., 2003). Negative effects of excess Mn on fish include anemia, leukocytosis, disruption of sodium balance, impaired calcium absorption and impacts on metabolism (Agrawal and Srivastava, 1980; Barnhoorn et al., 1999; Gonzalez et al., 1990; Nath and Kumar, 1987; Reader et al., 1988).

The presence of NO detected in the spectrum of fish liver samples may also be associated with $\mathrm{Fe}^{3+}$ domain in the spectrum of the same tissue, since the molecule exerts its physiological functions through the binding with $\mathrm{Fe}^{3+}$ present in heme (Denninger and Marletta, 1999). In fish, NO has important roles in cardiovascular homeostasis, neurotransmission, immune defenses, vasodilation, muscle performance and embryonic development (Eddy, 2005; Jensen, 2009; Moncada and Higgs, 2006; Rudnick et al., 2004), and may be potentially toxic depending 
on tissue concentration or clearance (Hansen and Jensen, 2010). In addition, NO production may be directly associated with hypoxias situations, where the increase in NO causes fish and other aquatic organisms to become more resistant to situations of low oxygen availability in water (Jensen, 2009; McNeill and Perry, 2006). Hansen and Jensen (2010), evaluating the production of NO in goldenfish (Carassius auratus Linnaeus, 1758), observed that in situations of severe hypoxia, NO production by fish was increased as well as its resistance capacity, since the vasodilatation caused by NO increased the oxygen delivery rate in the organs. Thus, it is possible to verify that presence of NO in the tissues of $P$. lineatus can be an indicative of the lack of oxygen in the water, which in the study site of the Batalha River is around $4.9 \mathrm{mg} / \mathrm{L}$, below the established limit by CONAMA for Class 2 waters (Conama, 2005). However, it would be necessary to quantify $\mathrm{NO}$ in the samples in order to obtain safer and more accurate results. Another factor that should be considered is the fact that NO production is also directly associated with production of nitrosamines, which are potentially carcinogenic organic compounds (Al Bulushi et al., 2009). In humans, the highest rate of exposure to this compound occurs through food, which includes water and fish (Dutra et al., 2007).

Humic acids (HA), derived from humic substances (HS), which are part of organic matter, belong to the class of natural products most abundant in the biosphere, being precursors of fossil fuels. They are the most-studied fraction of HS, since they can contain voids of different sizes in their molecular structures, and can accommodate a wide range of pollutants (Mangrich and Vugman, 1988). HA act as binders for the complexation of ions, mainly $\mathrm{Mn}^{2+}, \mathrm{Fe}^{3+}$ and $\mathrm{Cu}^{2+}$, where the formation and transport of these complexes, and their deposition, can be important mechanisms in the accumulation of metals in the sedimentary deposits (Saab, 1999). It is known that in HA the content of certain ions, such as $\mathrm{Fe}^{3+}$, in concentrate domain sites increases with decreases in the degree of environmental pollution (Silva, 2001). However, the mere presence of HA in the sediment spectrum cannot be considered an indicator of pollution, and a more robust analysis of its structure is necessary to establish relationships with environmental impacts such as forest-pasture conversion (Araújo et al., 2011) or pollution by heavy metals, pesticides and other substances of anthropogenic origin (Toscano, 1999).

\section{CONCLUSION}

In this study, the Electron Spin Resonance technique proved to be efficient in detecting transition metals (manganese, iron and copper) and nitric oxide and humic acid. However, low concentration values of these compounds in $P$. lineatus tissues (liver, muscle and intestine) and in water and sediment samples collected did not allow their quantification, as the concentration of metals in the tissues is at a level below the limit of detection. It can be concluded that $N$. curemai had the capacity to accumulate these ions, especially copper.

\section{ACKNOWLEDGMENTS}

We thank the Fundação de Amparo à Pesquisa do Estado de São Paulo (FAPESP) (process $n^{\circ}$ 2014/12682-0 and 07/06720-4) and the Coordenação de Aperfeiçoamento de Pessoal de Nível Superior - Brasil (CAPES) - Finance Code 001, for the financial support.

\section{REFERENCES}

AGRAWAL, S. J.; SRIVASTAVA, A. K. Haematological responses in a fresh water fish to experimental manganese poisoning. Toxicology, v. 17, p. 97-100, 1980. https://doi.org/10.1016/0300-483X(80)90031-1 
AL BULUSHI, I.; POOLE, S.; DEETH, H. C.; DYKES, G. A. Biogenic Amines in Fish: Roles in Intoxication, Spoilage, and Nitrosamine Formation - A Review. Critical Reviews in

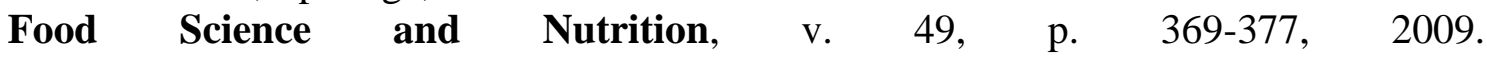
https://doi.org/10.1080/10408390802067514

ARAÚJO, E.; KER, J. C.; MENDONÇA, E. S.; SILVA, I. R; OLIVEIRA, E. K. Impacto da conversão floresta-pastagem nos estoques na dinâmica do carbono e substâncias húmicas do solo no bioma Amazônico. Acta Amazônica, v. 41, n. 1, p. 103-114, 2011.

BARNHOORN, I.; VAN VUREN, J. H. J.; PREEZ, H. H. Sublethal effects of manganese on the carbohydrate metabolism of Oreochromis mossambicus after acute and chronic exposure. African Zoology, v. 34, p. 102-107, 1999.

BARUŠ, V.; TENORA, F.; KRÁCMAR, S.; PROKES, M. Cadmium and lead concentrations in Contracaecum rudolphii (Nematoda) and its host, the cormorant Phalacrocorax carbo (Aves). Folia Parasitologica, v. 48, p. 77-78, 2001.

BARUŠ, V.; JARKOVSKÝ, J.; PROKEŠ, M. Philometra ovata (Nematoda: Philometroidea): a potential sentinel species of heavy metal accumulation. Parasitology Researh, v. 100, p. 929-933, 2007. https://doi.org/10.1007/s00436-006-0384-8

BAYOUMY, E. M.; ABOU-EL-DOBAL, S. K. A.; HASSANAIN, M. A. Assessment of Heavy Metal Pollution and Fish Parasites as Biological Indicators at Arabian Gulf off Dammam Coast, Saudi Arabia. International Journal of Zoological Research, v. 11, n. 5, p. 198206, 2015. http://dx.doi.org/10.3923/ijzr.2015.198.206

BRÁZOVÁ, T.; TORRES, J.; EIRA, C.; HANZELOVÁ, V.; MIKLISOVÁ, D.; ŠALAMÚN, P. Perch and Its Parasites as Heavy Metal Biomonitors in a Freshwater Environment: The Case Study of the Ružín Water Reservoir, Slovakia. Sensors, v. 12, p. 3068-3081, 2012. https://doi.org/10.3390/s120303068

BRÁZOVÁ, T.; HANZELOVÁ, V.; MIKLISOVÁ, D.; ŠALAMÚN, P.; VIDAL-MARTÍNEZ, V. M. Host-parasite relationships as determinants of heavy metal concentrations in perch (Perca fluviatilis) and its intestinal parasite infection. Ecotoxicology and $\begin{array}{llllll}\text { Environmental Safe, } & \text { n. } 122, \quad \text { p. } & \text { 551-556, } & \end{array}$ https://doi.org/10.1016/j.ecoenv.2015.09.032

BURY, N. R.; WALKER, P. A.; GLOVER, C. N. Nutritive metal uptake by teleost fish. Journal of Experimental Biology, v. 206, p. 11-23, 2003. https://dx.doi.org/10.1242/jeb.00068

CARVALHO, C. S.; FERNANDES, M. N. Effect of temperature on copper toxicity and hematological responses in the neotropical fish Prochilodus scrofa at low and high $\mathrm{pH}$. $\begin{array}{lllll}\text { Aquaculture, } & \text { v. } & 251, & \text { p. } & 109-117,\end{array}$ https://doi.org/10.1016/j.aquaculture.2005.05.018

CONSELHO NACIONAL DO MEIO AMBIENTE - CONAMA. Resolução nº 357, de 17 de março de 2005. Dispõe sobre a classificação dos corpos de água e diretrizes ambientais para o seu enquadramento, bem como estabelece as condições e padrões de lançamento de efluentes, e dá outras providências. Diário Oficial [da] União, n. 53, p. 58-63, 18 mar. 2015.

DENNINGER, J. W.; MARLETTA, M. A. Guanylate cyclase and the NO/cGMP signaling pathway. Biochimica and Biophysica Acta (BBA) - Bioenergetics, n. 1411, p. 334350, 1999. https://doi.org/10.1016/S0005-2728(99)00024-9 
D’ERRICO, G.; VITIELLO, G.; TOMMASO, G.; ABDEL-GAWAD, F. K.; BRUNDO, M. V.; FERRANTE, M. et al. Electron Spin Resonance (ESR) for the study of Reactive Oxygen Species (ROS) on the isolated frog skin (Pelophylax bergeri): A non-invasive method for environmental monitoring. Environmental Research, v. 165, p. 11-18, 2018. https://doi.org/10.1016/j.envres.2018.03.044

DI BENETITTO, A. P. M. D.; FRANCO, R. W. A. $\mathrm{Mn}^{2+}$ concentrations in coastal fish otoliths: understanding environmental and biological influences from EPR. Journal of Biological Physics, 2018. https://doi.org/10.1007/s10867-018-9502-y

DURAL, M.; GENC, E.; SANGUN, M. K.; GÜNER, O. Accumulation of some heavy metals in Hysterothylacium aduncum (Nematoda) and its host sea bream, Sparus aurata (Sparidae) from North-Eastern Mediterranean Sea (Iskenderun Bay). Environmental Monitoring and Assessment, v. 174, p. 147-155, 2011. https://doi.org/10.1007/s10661010-1445-0

DUTRA, C. B.; RATH, S.; REYES, F. G. Nitrosaminas voláteis em alimentos. Alimentos e Nutrição, v.18, p. 111-120, 2007.

EDDY, F. B. Role of nitric oxide in larval and juvenile fish. Comparative Biochemistry and Physiology Part A: Molecular \& Interative Physiology, v. 142, p. 221-230, 2005. https://doi.org/10.1016/j.cbpb.2005.05.038

FÖRStner, U.; WITMAnN, G. T. W. Metal Pollution in Aquatic Environment. 2. ed. Berlin: Spinger-Verlag, 1983. 485 p.

GOMES, M. A. F.; FILIZOLA, H. F. Amostragem de sedimento para análise de metais pesados. In: FILIZOLA, H. F.; GOMES, M. A. F.; SOUZA, M. D. (Eds.). Manual de procedimentos de coleta de amostras em áreas agrícolas para análise da qualidade ambiental: solo, água e sedimentos. Jaguariúna: Embrapa Meio Ambiente, 2006. p. 119124.

GONZALEZ, R. J.; GRIPPO, R. S.; DUNSON, W. A. The disruption of sodium balance inbrook charr, Salvelinus fontinalis (Mitchell), by manganese and iron. Journal of Fish Biology, v. 37, p. 765-774, 1990. https://doi.org/10.1111/j.1095-8649.1990.tb02540.x

HANSEN, M. N.; JENSEN, F. B. Nitric oxide metabolites in goldfish under normoxic and hypoxic conditions. Journal of Experimental Biology, v. 213, p. 3593-3602, 2010. Htttps://dx.doi.org/10.1242/jeb.048140

HOWE, P.; MALCOLM, H.; DOBSON, S. Manganese and its compounds: Environmental aspects. Geneva: World Health Organization, 2004, 63 p.

JENSEN, F. B. The role of nitrite in nitric oxide homeostasis: a comparative perspective. Biochimica et Biophysica. Acta (BBA) - Bionergetics, v. 1787, p. 841-848, 2009. https://doi.org/10.1016/j.bbabio.2009.02.010

KEEN, C. L.; ENSUNSA, J. L.; WATSON, M. H.; BALY, D. L.; DONOVAN, S. M.; MONACO, M. H. et al. Nutritional aspects of manganese from experimental studies. Neurotoxicology, v. 20, p. 213-223, 1999.

KHAN, R. A.; THULIN, J. Influence of pollution on parasites of aquatic animals. Advances in Parasitology, v. 30, p. 201-238, 1991. https://doi.org/10.1016/S0065-308X(08)60309-7

LAFFERTY, K. D. Ecosystem consequences of fish parasites. Journal of Fish Biology, n. 73, p. 2083-2093, 2008. https://doi.org/10.1111/j.1095-8649.2008.02059.x 
LAFFERTY, K. D.; KURIS, A. M. Parasitism and environmental disturbances. In: THOMAS, F.; RENAUD, F. L.; GUÉGAN, J. (Org.). Parasitism and Ecosystems. Oxford: Oxford University Press., 2005. p. 113-123.

LEITE, L. A. R.; PEDRO, N. H. O. P.; AZEVEDO, R. K.; KINOSHITA, A.; GENNARI, R. F.; WATANABE, S. et al. Contracaecum sp. parasitizing Acestrorhynchus lacustris as a bioindicator for metal pollution in the Batalha River, southeast Brazil. Science of the $\begin{array}{llllll}\text { Total Environment, } & \text { v. } & \text { 5. } & \text { 836, }\end{array}$ https://doi.org/10.1016/j.scitotenv.2016.09.132

LIM, C.; KLEUSIUS, P. H.; SHOEMAKER, C. A. Dietary Iron and Fish Health. In: LIM, C.; WEBSTER, C. D. Nutrition and Fish Health. New York: Food Products Press, 2001. p. 216-226.

MANGRICH, A. S.; VUGMAN, N. V. Bonding Parameters of Vanadyl ion in humic acid from the Jucu river estuarine Region, Brazil. Science of the Total Environment, v. 75, p. 235 241, 1988. https://doi.org/10.1016/0048-9697(88)90036-8

MCNEILL, B.; PERRY, S. F. The interactive effects of hypoxia and nitric oxide on catecholamine secretion in rainbow trout (Oncorhynchus mykiss). Journal of Experimental Biology, v. 209, p. 4214-4223, 2006. https://dx.doi.org/10.1242/jeb.02519

MERIAN, E.; ANKE, M.; IHNAT, M.; STOEPPLER, M. (Eds.). Elements and their compounds in the environment: occurrence, analysis and biological relevance. 2. ed. Weinheim: WILEY-VCH Verlag GmbH \& Co. KGaA, 2004. 1806 p.

MOMČILOVIĆ, B. The Copper Group. In: MERIAN, E.; ANKE, M.; IHNAT, M.; STOEPPLER, M. (Eds.). Elements and their compounds in the environment: occurrence, analysis and biological relevance. 2. ed. Weinheim: WILEY-VCH Verlag GmbH \& Co. KGaA, 2004. p. 731-750.

MONCADA, S.; HIGGS, E. A. The Discovery of nitric oxide and its role in vascular biology. British Journal of Pharmacology, n. 147, p. S193-S201, 2006. https://doi.org/10.1038/sj.bjp.0706458

MORSY, K.; MORSY, K.; BASHTAR, A. R.; ABDEL-GHAFFAR, F.; MEHLHORN, H.; QURAISHY, S. A. et al. First record of anisakid juveniles (Nematoda) in the European seabass Dicentrarchus labrax (family: Moronidae), and their role as bio-indicators of heavy metal pollution. Parasitology Research, v. 110, p. 1131-1138, 2012. https://doi.org/10.1007/s00436-011-2600-4

MURZAKHANOV, F.; MAMIN, G.; VOLOSHIN, A.; KLIMASHINA, E.; PUTLYAEV, V.; DORONIN, V. et al. Conventional electron paramagnetic resonance of $\mathrm{Mn}^{2+}$ in synthetic hydroxyapatite at different concentrations of the doped manganese. IOP Conference Series: Earth and Environmental Science, v. 155, p. 1-5, 2017. https://dx.doi.org/10.1088/1755-1315/155/1/012006

NACHEV, M.; ZIMMERMANN, S.; RIGAUD, T; SURES, B. Is metal accumulation in Pomphorhynchus laevis dependent on parasite sex or infrapopulation size? Parasitology, v. 137, 1239-1248, 2010. https://doi.org/10.1017/S0031182010000065

NACHEV, M.; SCHERTZINGER, G.; SURES, B. Comparison of the metal accumulation capacity between the acanthocephalan Pomphorhynchus laevis and larvae nematodes of the genus Eustrongylides sp. infecting barbell (Barbus barbus). Parasites \& Vectors, v. 6, n. 21, p. 1-8, 2013. https://doi.org/10.1186/1756-3305-6-21 
NATH, K; KUMAR, N. Toxicity of manganese and its impact on some aspects of Carbohydrate metabolism of a freshwater teleost, Colisa fasciatus. Science of the Total Environment, v. 67, p. 257-262, 1987. https://doi.org/10.1016/0048-9697(87)90216-6

PAPAGIANNIS, I.; KAGALOU, I.; LEONARDOS, J. PETRIDIS, D.; KALFAKAKOU, V. Copper and zinc in four freshwater fish species from Lake Pamvotis (Greece). $\begin{array}{llllll}\text { Environment International, } & \text { v. } 3004 .\end{array}$ https://doi.org/10.1016/j.envint.2003.08.002

PIRES, A. M. M.; SOUZA, M. D.; LIGO, M. A. V. Amostragem de água para análise de nitrato e de metais pesados. In: FILIZOLA, H. F.; GOMES, M. A. F.; SOUZA, M. D. (Eds.). Manual de Procedimentos de Coleta de Amostras em Áreas Agrícolas para Análise da Qualidade Ambiental: Solo, Água e Sedimentos. Jaguariúna: Embrapa Meio Ambiente, 2006. p. 103-106.

PORTO, L. C. S.; ETHUR, E. M. Elementos traço na água e em vísceras de peixes da Bacia Hidrográfica Butuí-Icamaquã, Rio Grande do Sul, Brasil. Ciência Rural, v. 39, n. 9, p. 2512-2518, 2009.

READER, J. P.; DALZIEL, T. R. K.; MORRIS, R. Groth, mineral uptake and skeletal calcium deposition in brown trout, Salmo trutta L., yolk-sac fry exposed to aluminium and manganese in soft acid water. Journal of Fish Biology, v. 32, p. 607-624, 1988. https://doi.org/10.1111/j.1095-8649.1988.tb05399.x

RUDNICK, J.; PÜTTMANN, B.; TESCH, P. A.; ALKNER, B.; SCHOSER, B. G.; SALANOVA, M. et al. Differential expression of nitric oxide synthases (NOS 1-3) in human skeletal muscle following exercise countermeasure during 12 weeks. FASEB J., v. 18, p. 1228-1230, 2004. https://doi.org/10.1096/fj.03-0792fje

SAAB, S. C. Caracterização da matéria orgânica em gleissolos por espectroscopias de EPR, RMN, IV e UV-Visível. 1999. Tese (Doutorado em Ciências) - Universidade de São Paulo, São Carlos, 1999.

SANTOS, F. S.; HEUBEL, M. T. C. D. Composição da comunidade ictiológica e biometria taxológica na lagoa de captação de água do DAE no rio Batalha (Bauru-SP). Salusvita, v. 27, n. 1, p. 29-44, 2008.

SÃO PAULO (Estado). Comitê da bacia hidrográfica do Tietê Batalha: fundamentos para implantação da cobrança pelo uso dos recursos hídricos. 2010. Disponível em: https://goo.gl/F4ienM. Acesso em: 23 set. 2016.

SCHMELLER, D. S.; LOYAU, A.; BAO, K.; BRACK, W.; CHATZINOTAS, A.; VLEESCHOUWER, F. et al. People, pollution and pathogens - Global change impacts in mountain freshwater ecosystems. Science of the Total Environment, v. 622-623, p. 756-763, 2018. https://doi.org/10.1016/j.scitotenv.2017.12.006

SCHÜMANN, K.; ELSENHANS, B. The Iron Group. In: MERIAN, E.; ANKE, M.; IHNAT, M.; STOEPPLER, M. (Eds.). Elements and their compounds in the environment: occurrence, analysis and biological relevance. 2. ed. Weinheim: WILEY-VCH Verlag GmbH \& Co. KGaA, 2004. p. 811-824.

SILVA, L. Estruturas químicas dos ácidos húmicos de sedimento de mangue e o nível de poluição ambiental. 2001. Dissertação (Mestrado em Química) - Universidade Federal do Paraná, Curitiba, 2001. 
SISTEMA NACIONAL DE INFORMAÇÕES SOBRE SANEAMENTO. Série histórica: informações sobre água e esgoto dos municípios brasileiros. 2016. Disponível em: http://app.cidades.gov.br/serieHistorica/\#. Acesso em: 23 set. 2016.

SURES, B. Environmental Parasitology: Interactions between parasites and pollutants in the aquatic environment. Parasite, v. 15, p. 434-438, 2008. https://doi.org/10.1051/parasite/2008153434

SURES, B.; NACHEV, M.; SELBACH, C.; MARCOGLIESE, D. J. Parasites responses to pollution: what we know and where we go in 'Environmental Parasitology'. Parasites \& Vectors, v. 10, p. 1-19, 2017. https://doi.org/10.1186/s13071-017-2001-3

SURES, B.; SIDALL, R.; TARASCHEWSKI, H. Parasites as accumulation indicators of heavy metal pollution. Parasitology Today, v. 15, p. 16-21, 1999. https://doi.org/10.1016/S0169-4758(98)01358-1

SURES, B.; TARACHEWSKI, H.; RYDLO, M. Intestinal fish parasites as heavy metal bioindicators: a comparison between Acanthocephalus lucii (Palaeacanthocephala) and the Zebra Mussel, Dreissena polymorpha. Bulletin of Environmental Contamination and Toxicology, v. 59, p. 14-21, 1997. https://doi.org/10.1007/s001289900437

THIELEN, F.; ZIMMERMAN, S.; BASKA, F.; TARASCHEWSKI, H.; SURES, B. The intestinal parasite Pomphorhynchus laevis (Acanthocephala) from barbel as a bioindicator for metal pollution in the Danube River near Budapest, Hungary. $\begin{array}{llllll}\text { Environmental Pollution, } & \text { v. 121, p. 421-429, }\end{array}$ https://doi.org/10.1016/j.envpol.2003.11.011

TOSCANO, I. A. S. Influência das substâncias húmicas aquáticas na determinação de atrazina por imunoensaio (elisa). 1999. Tese (Doutorado em Química) - Universidade Estadual Paulista "Júlio de Mesquita Filho", Araraquara, 1999.

VÄÄNÄNEN, K.; LEPPÄNEN, M. T.; CHEN, X.; AKKANEN, J. Metal bioavailability in ecological risk assessment of freshwater ecosystems: From science to environmental management. Ecotoxicology and Environmental Safety, v. 147, p. 430-446, 2018. https://doi.org/10.1016/j.ecoenv.2017.08.064

VIDAL-MARTÍNEZ, V. M.; PECH, D.; SURES, B.; PURUCKER, S. T.; POULIN, R. Can parasites really reveal environmental impact? Trends in Parasitology, v. 26, n. 1, p. 4451, 2009. https://doi.org/10.1016/j.pt.2009.11.001

VIDAL-MARTÍNEZ, V. M.; WUNDERLICH, A. C. Parasites as bioindicators of environmental degradation in Latin America: a meta-analysis. Journal of $\begin{array}{lllllll}\text { Helminthology, } & \text { v. } & 91, \quad \text { n. } & 2, & \text { p. } & 165-173,\end{array}$ https://doi.org/10.1017/S0022149X16000432

WEN, Y.; SCHOUPS, G.; van de GIESEN, N. Organic pollution of rivers: Combined threats of urbanization, livestock farming and global climate change. Scientific Reports, v. 7, p. 43289, 2017. https://doi.org/10.1038/srep43289

WERTZ, J.; BOLTON, J. R. Electron spin resonance: elementary theory and practical applications. New York: Springer Science \& Business Media, 2012. 498 p. 